\title{
Changing the (Video) Game: Innovation, User Satisfaction and Copyrights in Network Market Competition
}

\author{
Nachshon Goltz*, Jaimie Franks** and Shem Goltz***
}

\begin{abstract}
This paper explores the emerging trend of user-generated content and innovation in the development of new products and ideas, breaking the traditional producer-consumer paradigm that once dominated the marketplace. In particular, the paper evaluates and compares the relationship between innovation and user satisfaction within the video game industry. To do so, the paper assesses data collected from the online communities of two very different games, Minecraft and Call of Duty in order to determine if there is a link between user-innovation and user-satisfaction in a product. The authors predict that more innovation in a game leads to more user satisfaction. The results of the research do not support this prediction. As observed in the online communities of the two games, there is no clear connection between high levels of innovation with higher user satisfaction. In fact, there is no direct connection between innovation and user satisfaction. However, Minecraft was found to be the more innovative game of the two and did have an overall higher level of user satisfaction than compared to Call of Duty. The data also suggests that Minecraft players experience a greater fluctuation in their enjoyment of the game compared to the players of the game with less innovation, Call of Duty. Finally, "radical innovation" was only found in Minecraft and not in the game with less player-control. This paper then goes on to discuss the role of innovation and user-generated digital content within the realm of intellectual property law and the resulting copyright implications for video game producers and players alike.
\end{abstract}




\section{Introduction}

This paper assesses and compares innovation and user satisfaction with regards to the specific component of "game maps"1 in two highly popular and very different video games: Minecraft and Call of Duty. These observations are taken from the online communities of two dominant but very different online multi-player video games: the "user-generated" content-based Minecraft and the "company choice" content game Call of Duty. User satisfaction is based on users rating and feedback while the authors compare existing game maps to determine innovation level.

Radical innovation, or how new and innovative products the users perceive as being, has been the key to challenging monopolies. Innovation that is highly radical tends to break traditional designs and models, therefore becoming incompatible with the old, yet dominant, products. However, most innovative moves are not radical, but instead are positioned on the spectrum in between "not very new" and "substantially new but not paradigm breaking". In this context, the relationship between the creating firm and its customers is evolving. The traditional separation between producer and consumer is no longer the norm as technological developments in the innovation process have triggered new forms of collaboration between these parties. Nonetheless, while the phenomenon of open-source software has been thoroughly studied, the realm of digital entertainment and the emerging world of outsourcing innovation have yet to be investigated extensively. This paper addresses this gap in the context set above and provides an empirical study on this topic, specifically within the video game industry. Companies are now considering users in portions of the design and development of new products. Some firms in the digital entertainment field have furthered this trend by outsourcing the innovation process to their networks of consumers, almost exclusively. This process requires and indeed presents new and innovative copyright policies, which highlights the special characters and challenges inherent to the user-generated innovative content. Therefore, by allowing a portion of its digital content to be open to its consumers, the video game industry now allows and encourages its consumers to participate in the design of these games on a wide-scale along with adjusting its copyright policies to accommodate and encourage this trend.

\footnotetext{
${ }^{1}$ The landscape of the game. The virtual environment in which the user is playing the game. These environments can portray a City, a desert, imaginative environment and other options.
} 
This paper explores the interaction among innovation, user satisfaction and copyright regime in two highly popular online multiplayer video games: Minecraft and Call of Duty. The first began as an independent game with no advertising campaigns, and is therefore considered a phenomenon in the industry for its innovativeness and popularity. The second game holds a monopoly in the video game industry as the best-selling entertainment product currently in existence.

These two games are highly suitable for the research introduced in this paper with regard to the impact innovation has in network market competition. This is due to the fact that Minecraft is played using new game maps created by users and chosen by the users, while Call of Duty is played using new game maps that are created by the game producer, thus disallowing the user from choosing which new maps will be included in the game.

This Note examines the online communities of these two games to identify and understand the connection between the innovation levels of a set of new game maps and the corresponding user satisfaction from these game maps. The paper assumes that innovation level and user satisfaction will be significantly higher in Minecraft, where maps are user-generated and democratically chosen, than in Call of Duty, where the producer creates the game maps and the user has no choice.

This Note will first provide a background on the two games. Second, an outline of the theoretical frameworks that guide this analysis will be reviewed. The following section will discusses the research methodology - reviewing user feedback in online gaming communities to assess the levels of user satisfaction and rating the innovation level of the game maps. The results of the analysis will then be presented. Finally, a discussion of the results will lead into an exploration of the intellectual property law issues which innovative games, specifically Minecraft, bring forth.

\subsection{Minecraft}

Writing on cnet.com, Rich Brown ${ }^{2}$ describes Minecraft as follows:

Against the backdrop of multimillion-dollar AAA games and fun-yetbite-size downloadable titles, indie game Minecraft is an aberration. The product of lone developer Markkus 'Notch' Persson, Minecraft has

\footnotetext{
${ }^{2}$ Rich Brown, Indie game Minecraft offers tense, creative charm, CNET (20 September 2010), http://www.cnet.com/news/indie-game-minecraft-offers-tense-creative-charm/.
} 
ancient-looking graphics, no plot, and generates massive, sandbox game worlds with seemingly infinite creative possibilities, but no clear instructions telling you what to do or how to get started. Despite that seemingly user-unfriendly formula, Minecraft's buzz is so strong the server hosting its Web site crashed this weekend under the weight of incoming traffic. Spend an hour with Minecraft (which can easily spiral into two or three) and you'll quickly understand the reason for the enthusiasm around this indie hit. $^{3}$

Minecraft is one of the most recent yet unusual success stories in the video game industry. ${ }^{4}$ In less than two years Minecraft transformed from a small, independent game ${ }^{5}$ to a worldwide phenomenon. The game's creator has won a variety of accolades including the Independent Game Festival Seumas McNally Grand Prize award in 2011 and has earned millions of dollars. ${ }^{6}$

Microsoft recently bought the game for $\$ 2.5$ billion, a final proof of its monumental success. ${ }^{7}$ There are several ways to play Minecraft: (i) the original version of the game, "Minecraft Classic," offered for free on minecraft.net, (ii) a single-player mode, and (iii) a one where players have access to multi-player shared Minecraft servers.

\subsection{Call of Duty}

Call of Duty is a video game franchise of first-person and third-person shooter games, with several spin-off games available as well. Originally a computer game, it can now also be played on video game consoles and handheld devices. The earliest Call of Duty games were set primarily in World War II, including Call of Duty, Call of Duty 2, and Call of Duty 3.

Activision publishes and owns Call of Duty, while the studio Infinity Ward remains the primary developer of the games. Activision claims that the franchise has exceeded $\$ 11$ billion in revenue since its initial launch in 2003. ${ }^{8}$ In March 2011 "Call of Duty: Black Ops" was the best-

\footnotetext{
${ }^{3}$ Ibid.

${ }^{4}$ Sean C. Duncan, "Minecraft, Beyond Construction and Survival," (2011) 1:1 Well Played: a journal on video games, value and meaning 1, http://dl.acm.org/citation.cfm?id=2207097.

${ }_{5}^{5}$ Minecraft, What is Minecraft? (About the Game), https://minecraft.net/game.

${ }^{6}$ Matthew Lynley, Indie sandbox game Minecraft racks up 1 million sales without a publisher, VENTURE BEAT (12 January 2011), http://venturebeat.com/2011/01/12/indie-sandbox-game-minecraft-racks-up-1-million-sales-sans-apublisher/.

${ }^{7}$ Christian Bautista, Microsoft buys 'Minecraft' for $\$ 2.5$ billion. Has 'Notch' Persson done the right thing?, TECH TiMES (20 September 2014), http://www.techtimes.com/articles/15797/20140920/microsoft-buys-minecraft-for-2-5billion-has-markus-notch-persson-done-the-right-thing.htm.

${ }^{8}$ Matt Miller, Call Of Duty Tops $\$ 11$ Billion In Revenue, GAME INFORMER (5 February 2015), http://www.gameinformer.com/b/news/archive/2015/02/05/call-of-duty-tops-11-billion-in-revenue.aspx. The numbers are cited based on information from the NPD Group and GfK Chart-Track.
} 
selling video game ever, reportedly selling an approximate 23 million copies worldwide. ${ }^{9}$

\section{Theoretical Framework}

The economic theories framing the research and context of this paper are set forth below. First, the concept of "network effects" are defined and explored. The impact of these network effects on competition in the marketplace is then discussed. Stemming from the issue of competitive networks comes the introduction of innovation in the market, specifically its [innovation] use in the product development process and its influence on both competition and the traditional economic model of producer-consumer relationships. From there this paper looks at the role of digital consumer networks and firm hosted commercial online communities in this new market of innovation.

In undertaking this theoretical framework to anchor this paper, the authors are able to investigate how innovation has influenced competition and production within the marketplace, and how these influences are reflected in the related consumer networks. More narrowly, how innovation is reflected within the online communities of digital entertainment firms.

\subsection{Network Effects and Conditions of Entry}

The benefit a consumer derives from consumption of a product may depend not only on the amount he consumes, ${ }^{10}$ but also on how many others consume it or the total amount consumed. ${ }^{11}$ A classic example is telephone service: The value to each individual telephone subscriber increases as the number of subscribers increases, since the addition of new subscribers increases each subscriber's ability to communicate with others. The telephone subscribers form a "network," the size of which is indicated by the number of subscribers, and the consumer benefit from increased network size is termed a "network effect." ${ }^{12}$ Telephones illustrate "direct network

\footnotetext{
${ }^{9}$ Ana Douglas, Here Are The 10 Highest Grossing Video Games Ever, BusInESS InSIDER (13 June 2012), http://www.businessinsider.com/here-are-the-top-10-highest-grossing-video-games-of-all-time-20126?op=1\#ixzz3ULx9uMlz.

${ }^{10}$ For other non-technical discussions of the economics of networks, see CARL SHAPIRO AND HAL R. VARÍAN, INFORMATION RULES ch. 7 (1999); SJ. Liebowitz \& Stephen E. Margolis, Network Effects and Externalities, in THE NeW PAlgRAVE Dictionary of ECONOMICS AND THE LAW 671 (Peter Newman ed., 1998); Nicholas Economides, The Economics of Networks, 14 INT'L J. INDUS. ORG. 673 (1996).

11 This possibility was discussed in economic literature long before the concept of network effects was introduced. See Harvey Leibenstein, Bandwagon, Snob, and Veblen Effects in the Theory of Consumers' Demand, 64:2 QJ. ECON. 183 (1950)

${ }^{12}$ See generally Michael L. Katz \& Carl Shapiro, Technology Adoption in the Presence of Network Externalities, 94:4 J. POL. ECON. 822 (1986); Michael L. Katz \& Carl Shapiro, Network Externalities, Competition, and Compatibility, 75:3 AM. ECON. REV. 424 (1985); Production in "network industries," e.g., airlines, electric power,
} 
effects," since consumer benefits stem directly from increased network size. ${ }^{13}$ Direct network effects often arise when consumers share. Demand for a television program or movie may exhibit a network effect if consumers derive utility from sharing their viewing experiences with friends. Sharing with others also may have more tangible benefits, which generate network effects in other ways. The benefits of PC ownership may increase with the size of the network of friends and coworkers who can help with problems. ${ }^{14}$ The benefits from adopting a particular PC application program may also increase with the size of the network of individuals who can share files. ${ }^{15}$ A single application program may present a clear choice to many users due to it becoming an industry standard and thus must be used in order to do business efficiently, or at all, with other users. ${ }^{16}$ There are also "indirect network effects." They do not arise from a growth in the size of the network, but from the effect the larger network has on the production of complements. ${ }^{17}$ Increased sales of compact disc players stimulated the production of compact discs, which further increased demand for compact disc players. ${ }^{18}$ Economists have cited indirect network

and telecommunications (see, e.g., Deregulation of Network Industries (Sam Peltzman \& Clifford Winston eds., 2000)), involves physical networks, which also have important implications for conditions of entry, but "network effects" relate to demand rather than production.

${ }^{13}$ A similar phenomenon arises when a product attracts more consumers by offering greater availability. An example is an ATM network, for which this effect has been documented empirically. See Garth Saloner \& Andrea Shepard, Adoption of New Technologies with Network Effects: An Empirical Examination of the Adoption of Automatic Teller Machines, 26:3 RANDJ. ECON. 479 (1995).

${ }^{14}$ For empirical documentation of this effect, see Austan, Goolsbee \& Peret, J. Klenow, Evidence of Learning and Network Externalities in the Diffusion of Home Computers (NBER Working Paper 7329 Sept. 1999), http://gsbwww.uchicago.edu/fac/ austan.goolsbee/research/computer.pdf.

${ }^{15}$ For empirical evidence of this effect, see Neil Gandal, Hedonic Price Indexes for Spreadsheets and an Empirical Test for Network Externalities, 25:1 RAND J. ECON. 160 (1994).

16 This was argued to be the case for Lotus 1-2-3. See Brief Amicus Curiae of Economics Professors and Scholars in Support of Respondent, Lotus Dev. Corp. v. Borland Int'l, Inc., S. Ct. No. 94-2003, 1995 WL 728562. The court of appeals in this case noted the potential importance of network effects. 49 F.3d 807, 819-20 (1 $1^{\text {st }}$ Cir. 1995) (Boudin, J., concurring).

${ }^{17}$ See generally Neil Gandal, "A Selective Survey of the Literature on Indirect Network Externalities: A Discussion of Liebowitz and Margolis," (1995) 17 Research in Law and Economics 1 (Richard O. Zerbe, Jr. \& William Kovacic eds., 1995). For empirical evidence of an indirect network effect in the software industry, see Neil Gandal, Competing Compatibility Standards and Network Externalities in the PC Software Market, 77:4 REV. ECON. \& STAT. 599 (1995).

${ }^{18}$ For an empirical analysis of the interaction between compact discs and compact disc players, see Neil Gandal, Michael Kende \& Rafael Rob, The Dynamics of Technological Adoption in Hardware/Software Systems: The Case of Compact Disc Players, 31:1 RAND J. ECON. 43 (2003). 
effects as a major factor in Microsoft's displacement of what had been the leading PC operating system. ${ }^{19}$

Network effects can have significant implications for competition. ${ }^{20}$ When two networks compete head-to-head, the larger one offers consumers a cost or quality advantage (other things being equal), which, by the nature of network effects, attracts additional consumers to it. This feedback mechanism tends to cause the larger network to grow further, while the smaller network shrinks. When this feedback mechanism is sufficiently more powerful relative to the other economic forces at work, markets experience "tipping," i.e., when one network is sufficiently larger than rival networks, the rivals tend to shrink and perhaps disappear. An oftencited example of market tipping is the VCR industry, in which the Beta technology essentially vanished due to the success of the VCR. ${ }^{21}$ With strong network effects, a product or technology standard can lose out to an objectively inferior alternative due to network size advantage. ${ }^{22}$ However, whether there are significant examples of this having actually occurred is a matter of some debate. ${ }^{23}$ It is also theoretically possible for established networks to be displaced by upstart rivals when the established networks are not socially efficient. ${ }^{24}$

If network effects are particularly distinct, competition may be fundamentally "for the market," instead of "in the market." This is sometimes referred to as "Shumpeterian

\footnotetext{
${ }^{19}$ Microsoft, IBM, and independent applications developers created sufficient applications for MS-DOS that users preferred it to the previously dominant CP/M. See Neil Gandal, Shane Greenstein \& David Salant, Adoptions and Orphans in Early Microcomputer Market, 47:1 J. INDUS. ECON. 87 (1999).

${ }^{20}$ For useful discussions of competition in the presence of indirect network effects, see Stanley M. Besen \& Joseph Farrell, Choosing How to Compete: Strategies and Tactics in Standardization, 8:2 THE JouRnal OF ECONOMIC PERSPECTIVES. 117 (1994); Michael L. Katz \& Carl Shapiro, Systems Competition and Network Effects, 8:2 THE JOURNAL OF ECONOMIC PERSPECTIVES 93 (1994).

${ }^{21}$ See, e.g., SJ. Liebowitz and Stephen E. Margolis Are Network Externalities a New Source of Market Failure?," (1995) 17 Research in Law and Economics 1 (Richard O. Zerbe, Jr. \& William Kovacic eds., 1995); W. Brian Arthur, Positive Feedback in the Economy, 262 SCIENTIFIC AM. 92 (1990)

${ }^{22}$ See W. Brian Arthur, Competing Technologies, Increasing Returns, and Lock-In by Historical Events, 99:394 ECON. J. 116 (1989); Paul A. David, Clio and the Economics of QWERTY, 75 AM. ECON. REV. (Papers \&Proc.) 332 (1985); Joseph Farrell \& Garth Saloner, Standardization, Compatibility, and Innovation, 16:1 RAND J. Econ. 70 (1985).

${ }^{23}$ Liebowitz \& Margolis, supra note 171, at 120-27; Path Dependence, Lock-In and History, 11 J.L. ECON. \& ORG. 205 (1995); Network Externality: An Uncommon Tragedy, ECON. PERSP. 133 (Spring 1994); The Fable of the Keys, 33 J.L. \& ECON. 1 (1990).

${ }^{24}$ See Jeffrey Church \& Neil Gandal, Complementary Network Externalities and Technology Adoption, 11:2 INT'L J. INDUS. ORG. 239 (1993); Michael L. Katz \& Carl Shapiro, Product Introduction and Network Externalities, 40:1 J. INDUS. ECON. 55 (1992).
} 
competition." ${ }^{25}$ At any given time, the tipping phenomenon may effectively leave room for a single major network, while an incumbent dominant network competes with potential entrants to hold that position. A potential new firm entering into a market with network effects faces disadvantages the established firm does not. That is because, "without some off-setting advantage, the potential entrant has no prospect of success". ${ }^{26}$

Offering an advantage to a relatively small group of consumers may suffice to permit the entrant to prosper in a market niche, but to seriously challenge the position of a dominant incumbent, a potential entrant must offer a substantial advantage to consumers generally. This advantage may be a lower price. However, incumbent products or standards protected by significant network effects generally have been successfully challenged only by major innovations offering something the incumbent cannot match by cutting price. ${ }^{27}$ Indirect network effects are apt to present somewhat different obstacles to potential entrants than direct network effects seeing as the potential entrant's disadvantage relates to the availability of complements of various sorts.

To the extent that the complements are incompatible in some way, an entrant might have to establish its own complementary network. An entrant into automobile production, for example, needs a sales and service network, which may present a significant obstacle even if rivals' dealers can be used, and entrants may suffer a disadvantage from having smaller sales and service networks than established rivals. Entry may be exceptionally difficult if an entrant cannot directly establish the complementary network itself, but rather must rely on multiple independent complementers to support its product.

This presents a "collective-action problem." ${ }^{28}$ It may be rational for any one complementer to support an entrant's product only if other complementers do so, because only the support of

\footnotetext{
${ }^{25}$ The term derives from a description of dynamic competition by economist Joseph A. Schumpeter in his most widely read work, CAPITALISM, SOCIALISM, AND DEMOCRACY ch. 7 (3d ed. 1950). Schumpeter called this competition a "Process of Creative Destruction."

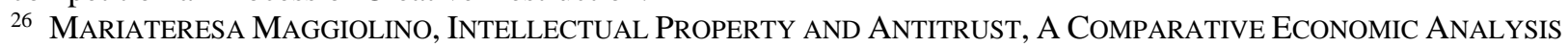
OF US AND EU LAW 20 (Edward Elgar, UK (2011).

${ }^{27}$ For a similar discussion in the specific context of PC software, see David S. Evans \& Richard L. Schmalensee, Be Nice to Your Rivals: How the Government Is Selling an Antitrust Case Without Consumer Harm in United States $v$. Microsoft, in DiD Microsoft HARM Consumers? Two OpPosing Views 45, 65-66 (David S. Evans et al., 2000).

${ }^{28}$ A collective-action problem is a type of free-rider problem commonly associated with public goods, such as national defense. Although it is in the collective interest of a group to undertake some action, e.g., defend the country from foreign attack, individual members of the group lack a sufficient incentive to act unilaterally and coordination among members of the group is difficult. See generally Mancur Olson, "Collective Action," (1994) 1
} 
many complementers would permit the entrant to succeed to the point at which any of the complementers profit from supporting the entrant. The producer of a motor vehicle using an entirely new fuel would face this sort of difficulty in getting gasoline stations to distribute the new fuel, even though the stations might find distributing it profitable when enough of them do so and the new technology is widely adopted by the car-buying public.

\subsection{Competing through Innovation in Network Markets}

Those who research strategic management and economics have discussed the ways in which new firms can challenge and replace established firms in non-network markets. ${ }^{29}$ These researchers have found that technological discontinuities provide opportunities for challengers to enter the marketplace, and that incumbents may find it difficult to adapt to environmental change. ${ }^{30}$

Economic models "may [also] overstate the extent to which preemptive actions help monopolies". ${ }^{31}$ Reinganum ${ }^{32}$ found that, "preemption helped monopolies persist when challenged by incremental innovation, but radical innovation helped firms challenge monopolies". ${ }^{33}$ Reinganum also found that the extent of this radicalism is important too. Many researchers treat innovation as if it is either radical yet incompatible or incremental and

The New PAlgrave: A Dictionary OF ECONOMiCs 474 (John Eatwell et al. eds., 1994); MANCUR OLSON, ThE Logic Of Collective ACTION ch. 1 (2d ed. 1971); R.H. Coase, The Problem of Social Cost, 3 J.L. \& ECON. 1 (1960). Collective-action problems are familiar in law. See, e.g., Frank I. Michelman, Property, Utility, and Fairness: Comments on the Ethical Foundations of "Just Compensation" Law", 80:6 HARV. L. REV. 1165, at 117476 (1967). Collective-action problems are commonplace in antitrust. The benefits of competition derive from the fact that competitors normally cannot solve their collective-action problem and act in concert, rather than compete. In addressing collusion and monopoly, it has been argued that antitrust law is preferred to contract law because a collective-action problem prevents the victims of collusion and monopoly from contracting away such problems. See Guido Calabresi, Transaction Costs, Resource Allocation and Liability Rules-A Comment, 11 J.L. \& ECON. 67, at 70-71 (1968).

${ }^{29}$ See Willow A. Sheremata, Competing through Innovation in Network Markets: Strategies for Challengers, 29:3 THE ACADEMY OF MANAGEMENT REVIEW 359 (2004).

${ }^{30}$ P. Anderson \& M.L. Tushman, Technological discontinuities and dominant designs: A cyclical model of technological change, 35 ADMINISTRATIVE SCIENCE QUARTERLY, $51-73$ (1990); M.B. Lieberman \& D. B. Montgomery, First-mover advantage, 9 STRATEGIC MANAGEMENT JoURNAL 41-58 (1988); M.L.Tushman \& P. Anderson, Technological discontinuities and organizational environments, 31 ADMINISTRATIVE SCIENCE QUARTERLY, 439-465 (1986).

${ }^{31}$ Richard J. Gilbert \& David M. G. Newberry, Preemptive Patenting and the Persistence of Monopoly, 72:3 AMERICAN ECONOMIC REVIEW 514 (1982)

32 Jennifer F. Reinganum, Uncertain Innovation and the Persistence of Monopoly, 73:4 AMERICAN ECONOMIC

REVIEW 741 (1983).

${ }^{33}$ Sheremata, supra note 29.

(C) 2015 Journal of Law, Technology and Public Policy and

Nachshon Goltz, Jamie Franks, and Shem Goltz 
compatible, rather "than a point in two-dimensional space". ${ }^{34}$ However, how radical and how compatible a new innovation is are both matters of degree, the first moving from incremental (small) improvements to radical (large) improvements and the second from perfect compatibility to perfect incompatibility.

Innovative moves that are highly radical tend to break traditional designs and models, therefore becoming incompatible with the old, yet dominant, products. ${ }^{35}$ However, most innovative moves are not radical, but instead sit in between "not very new" and "substantially new but not paradigm breaking". ${ }^{36}$

\subsection{Digital Consumer Networks and Producer-Consumer Collaboration}

Traditionally, the producer designs, makes, and distributes new goods. ${ }^{37}$ Consumers then buy these products, with no input on the design, production or distribution process of the firm. Consumer input tends to be limited market research activities or customer reviews. As such, a classical understanding of economics assumes a strict separation between producers and consumers, with collaboration only occurring between different producers in joint venture partnerships. $^{38}$

The relationship between the creating firm and its customers is evolving. The traditional separation between producer and consumer is no longer the norm as technological developments in the innovation process have triggered new forms of collaboration between these producers and consumers, allowing the relationship between a firm and its customers to change. ${ }^{39}$ As such, there is a relaxation and step away from the conventional belief that producers and consumers

\footnotetext{
34 Ibid.

${ }^{35}$ Giovanni Dosi, Technological paradigms and technological trajectories: A suggested interpretation of the determinants and direction of technological change, 11:3 RESEARCH POLICY 147 (1982); Rebecca M. Henderson \& Kim B. Clark, Architectural Innovation: The Reconfiguration of Existing Product Technologies and the Failure of Established Firms, 35:1 AdMINISTRATIVE SCIENCE QUARTERLY 9 (1990).

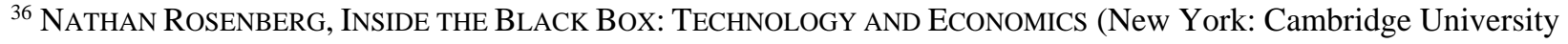

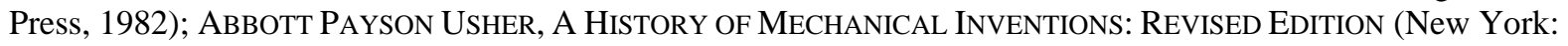
McGraw-Hill, 1954).

${ }^{37}$ See Reina Y Arakji \& Karl Reiner Lang, Digital Consumer Networks and Producer-Consumer Collaboration: Innovation and Product Development in the Video Game Industry, 24:2 J. OF MANAGEMENT INFORMATION SYSTEMS 195 (2007).

${ }^{38}$ Patrick Greenlee, Endogenous Formation of Competitive Research Sharing Joint Ventures, 53:3 THE JOURNAL OF INDUSTRIAL ECONOMICS 355 (2005).

${ }^{39}$ Satish Nambisan, Information Systems as a Reference Discipline for New Product Development, 27:1 MIS QUARTERLY 1 (2003); Stefan Thomke \& Eric von Hippel, Customers as Innovators: A New Way to Create Value, HARVARD BUSINESS REVIEW (2002), https://hbr.org/2002/04/customers-as-innovators-a-new-way-to-create-value.
} 
are completely separate entities. We have already seen this phenomenon in the creation of new medical and sports products, as influenced by trendsetters in those industries. ${ }^{40}$ This outsourcing has now shifted, at an unprecedented level, to the digital realm; beginning with open-source software projects and now to the digital entertainment industry. ${ }^{41}$

\subsection{Digital Consumer Networks}

While many companies consider their consumers in the development of new products, some firms in the digital entertainment industry have gone a step further by outsourcing the innovation process to their user-networks. According to Von Hippel, "lead-users are consumers who experience needs for particular products ahead of the general users who will develop these needs later on". ${ }^{42}$ They therefore are "need-forecasting" agents, inspiring new product designs that meet these needs. On the other hand, this paper defines digital consumer networks as online communities of consumers. These communities share similar interests and use the Internet to connect with likeminded users to discuss digital products as well as take part in their design, development, and distribution. ${ }^{43}$

Through opening a portion of their proprietary digital content to the public for input and transformation, the firms are thus allowing these networks to create new products that can in turn be used in the innovation process. Doing so, however, transfers some of the intellectual property rights from the producer to their consumers. The video game industry has proven to be a leader in this opening and making available of digital content to consumers in the hopes of userparticipation in wide-scale product design. ${ }^{44}$

\subsection{Firm-hosted Commercial Online Communities}

Online communities were originally created with the intention to generate the "sense of belonging that was lost during the shift from community to society." 45 People found other similar

\footnotetext{
${ }^{40}$ ERIC VON HiPPEL, DEMOCRATIZING INNOVATION (Cambridge: MIT Press, 2005).

${ }^{41}$ LAWrence Lessig,,Free Culture: How Big Media Uses TeChNOlOGY AND the LAw to Lock Down Culture And Control Creativity (New York: The Penguin Press, 2004).

${ }^{42}$ Eric von Hippel, Lead Users: A Source of Novel Product Concepts, 32:7 MANAGEMENT SCIENCE 791 (1986).

${ }^{43}$ Reina Arakji and Karl Lang, Digital Consumer Netowrks and Producer-Consumer Collaboration: Innovation and Product Development in the Video Game Industry, Journal of MANAGEMENT InFORMATION SySTEMS (2007). Internet Consumers' Behaviors, 23:1 AdvANCES IN CONSUMER RESEARCH 178 (1996); See Caroline Wiertz \& Ko de Ruyter, Beyond the Call of Duty: Why Customers Contribute to Firm-hosted Commercial Online Communities, 28:3 ORGANIZATION STUDIES 347 (2007).
} 
individuals online as a way to foster support, connections, and exchange information. ${ }^{46}$ By the mid-1990s, the commercial potential of these groups was recognized and disseminated in business management materials. ${ }^{47}$ As a result numerous organizations began to explore opportunities for building their own communities online.

These company-hosted online communities of customers are where this paper focuses its research. We define these communities as networks of firm customers who come together to coproduce and consume content in a shared interest through the exchange of intangible resources. These intangible resources can include: information, knowledge, and socio-emotional support, to name a few. ${ }^{48}$

\section{Method}

The tables on the following pages describe the new game maps that were used in this research. User-satisfaction was assessed on a scale of 1-10 based on users' ratings and written feedback in the online communities of Minecraft and Call of Duty. The innovation level was assessed by the authors on a scale of 1-10 in comparison to existing game maps. Innovation levels of 8 or higher are considered radical. Statistical analysis was done using SSPS software. Before discussing the results of the user-satisfaction assessment, each of the Minecraft and Call of Duty game maps are described below.

\section{$\underline{\text { Minecraft }^{49}}$}

\begin{tabular}{|c|c|c|c|}
\hline Map Name & Date & Description & Visual \\
\hline Memory of Earth & April 25, 2014 & Overgrown Town & \\
& & & \\
\hline
\end{tabular}

\footnotetext{
${ }^{46}$ StACEY E. BRESSLER \& CHARLES E. GRANTHAM, COMMUNITIES OF COMMERCE: BuILDING INTERNET BuSinESS COMMUNITIES TO ACCELERATE Growth, Minimize Risk, AND INCREASE CUSTOMER LOYALTY (New York: McGraw-Hill, Inc., 2000).

${ }^{47}$ John Hagel \& Arthur G. Armstrong, Net gain: Expanding Markets Through OnLine Communities (Harvard Business School Press, 1997).

${ }^{48}$ Brian Butler, Lee Sproull, Sara Kiesler \& Rober Kraut, Community Effort in Online Groups: Who Does the Work and Why? in SUZANNE P. WEISBAND (ED.), LEADERSHIP AT A DisTANCE: RESEARCH IN TECHNOLOGICALlYSUPPORTED WORK (New York: Taylor \& Francis Group, LLC, 2008).

${ }^{49}$ Minecraft, http://www.minecraftsurvivalgames.com/forums/AcceptedMaps/
} 


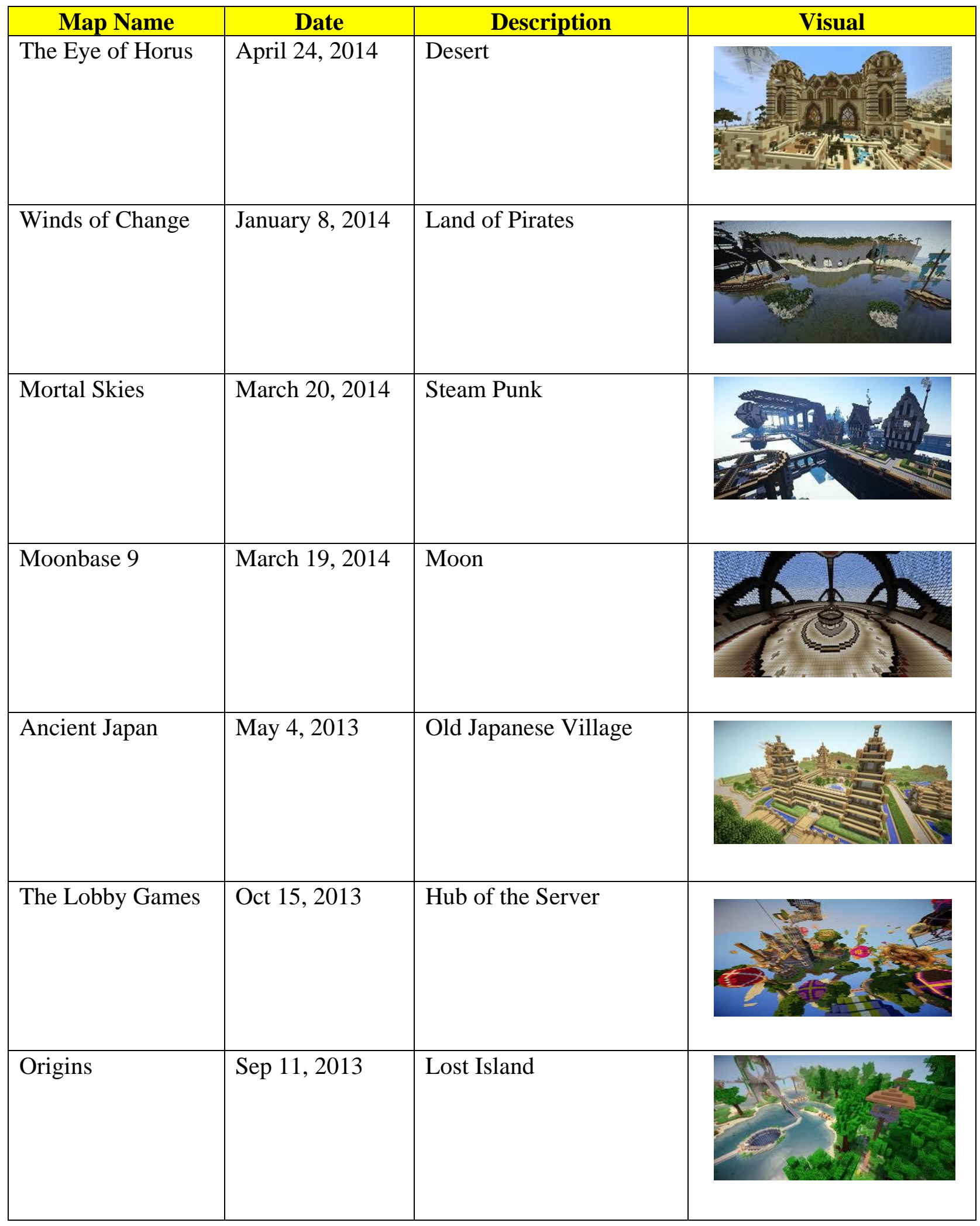




\section{Call of Duty ${ }^{50}$}

\begin{tabular}{|c|c|c|c|}
\hline Map Name & Date & Description & Visual \\
\hline Fog & January 28, 2014 & Dark Campsite & \\
\hline Bay View & January 28, 2014 & $\begin{array}{l}\text { Coastal Californian } \\
\text { Boardwalk }\end{array}$ & \\
\hline Containment & January 28, 2014 & Mexican Village & \\
\hline Ignition & January 28, 2014 & $\begin{array}{l}\text { Aging Space Launch } \\
\text { Facility }\end{array}$ & \\
\hline Ruins & April 3, 2014 & Mayan Jungle & \\
\hline Behemoth & April 3, 2014 & $\begin{array}{l}\text { Massive Excavation } \\
\text { Vehicle }\end{array}$ & \\
\hline
\end{tabular}

\footnotetext{
${ }^{50} \mathrm{http} / / /$ community.callofduty.com/community/call_of_duty/english/ghosts/forums; http://community.callofduty.com/community/call_of_duty/english/ghosts/forums/general_discussion/search.jspa?q= maps
}

(C) 2015 Journal of Law, Technology and Public Policy and Nachshon Goltz, Jamie Franks, and Shem Goltz 


\begin{tabular}{|l|l|l|c|}
\hline \multicolumn{1}{|c|}{ Map Name } & \multicolumn{1}{|c|}{ Date } & Description & \multicolumn{1}{|c|}{ Visual } \\
\hline Unearthed & April 3,2014 & An Alien Dig Site & \\
\hline Collision & April 3,2014 & $\begin{array}{l}\text { Cargo Ship Crushed } \\
\text { into Bridge }\end{array}$ & \\
\hline
\end{tabular}

\section{Results}

The assessment generated the following results:

\section{Minecraft $^{51}$}

\begin{tabular}{|l|c|l|c|c|}
\hline \multicolumn{1}{|c|}{ Map Name } & \multicolumn{1}{|c|}{ Date } & \multicolumn{1}{c|}{ Description } & $\begin{array}{c}\text { Innovation } \\
\text { level }\end{array}$ & $\begin{array}{c}\text { User } \\
\text { Satisfaction }\end{array}$ \\
\hline Memory of Earth & April 25, 2014 & Overgrown Town & 9 & 5 \\
\hline The Eye of Horus & April 24, 2014 & Desert & 7 & 8 \\
\hline Winds of Change & January 8, 2014 & Land of Pirates & 6 & 7 \\
\hline Mortal Skies & March 20, 2014 & Steam Punk & 8 & 6 \\
\hline Moonbase 9 & March 19, 2014 & Moon & 7 & 8 \\
\hline Ancient Japan & May 4, 2013 & Old Japanese village & 6 & 7 \\
\hline The Lobby Games & Oct 15, 2013 & Hub of the Server & 8 & 9 \\
\hline Origins & Sep 11, 2013 & Lost Island & 10 & 8 \\
\hline
\end{tabular}

\section{Call of Duty ${ }^{52}$}

\begin{tabular}{|l|l|l|c|c|}
\hline \multicolumn{1}{|c|}{ Map Name } & \multicolumn{1}{|c|}{ Date } & \multicolumn{1}{c|}{ Description } & $\begin{array}{c}\text { Innovation } \\
\text { level }\end{array}$ & $\begin{array}{c}\text { User } \\
\text { Satisfaction }\end{array}$ \\
\hline Fog & January 28, 2014 & Dark Campsite & 7 & 7 \\
\hline Bay View & January 28, 2014 & $\begin{array}{l}\text { Coastal Californian } \\
\text { Boardwalk }\end{array}$ & 4 & 7 \\
\hline
\end{tabular}

${ }^{51} \mathrm{http}: / / \mathrm{www} . \mathrm{minecraftsurvivalgames.com/forums/AcceptedMaps/}$

$52 \mathrm{http} / / /$ community.callofduty.com/community/call_of_duty/english/ghosts/forums;

http://community.callofduty.com/community/call_of_duty/english/ghosts/forums/general_discussion/search.jspa?q= maps

(C) 2015 Journal of Law, Technology and Public Policy and

Nachshon Goltz, Jamie Franks, and Shem Goltz 


\begin{tabular}{|l|c|l|c|c|}
\hline \multicolumn{1}{|c|}{ Map Name } & \multicolumn{1}{|c|}{ Date } & \multicolumn{1}{c|}{ Description } & $\begin{array}{c}\text { Innovation } \\
\text { level }\end{array}$ & $\begin{array}{c}\text { User } \\
\text { Satisfaction }\end{array}$ \\
\hline Containment & January 28, 2014 & Mexican Village & 4 & 7 \\
\hline Ignition & January 28, 2014 & $\begin{array}{l}\text { Aging Space Launch } \\
\text { Facility }\end{array}$ & 4 & 7 \\
\hline Ruins & April 3, 2014 & Mayan Jungle & 5 & 5 \\
\hline Behemoth & April 3, 2014 & $\begin{array}{l}\text { Massive Excavation } \\
\text { Vehicle }\end{array}$ & 5 & 5 \\
\hline Unearthed & April 3, 2014 & An Alien Dig Site & 5 & 5 \\
\hline Collision & April 3, 2014 & $\begin{array}{l}\text { Cargo Ship Crushed } \\
\text { into Bridge }\end{array}$ & 5 & 5 \\
\hline
\end{tabular}

Overall, an analysis of the results shows insignificant negative correlation between innovation and satisfaction - the higher the innovation the lower the satisfaction and vice versa. When comparing across the games, Minecraft is higher in innovation with a mean of 7.62 while Call of Duty has a mean is 4.87. Minecraft is also higher in user satisfaction with a mean of 7.25 while Call of Duty has a mean of 6.0.

Half of the Minecraft game maps were found to be radically innovative. In comparison, Call of Duty ranks low in innovation level, with only one game map ranking at above a 5. Call of Duty innovation level averages at 4.9.

\section{Discussion}

The results do not support the paper's prediction that there will be a significant positive correlation between innovation and user satisfaction. Nonetheless, it does support the prediction that both innovation and user satisfaction will be higher in Minecraft than in Call of Duty. The first prediction is based on the assumption that innovative game maps enhance user satisfaction and vice-versa. The second prediction was based on the reasoning that where the maps are user generated and a player would have more control over the game maps in which the game is played, both the innovation and his or her user experience and overall enjoyment would be heightened.

Firstly, it seems as if more innovation does not necessarily mean more user satisfaction. There is no clear connection between higher levels of innovation with higher user satisfaction. Although in Minecraft the extremely innovative game map "Lost Island" (innovation =10) had a similarly high level of user satisfaction (user satisfaction $=8$ ), at the same time the innovative game map “Overgrown Town” (innovation =9) only had a user satisfaction level of 5. 
Furthermore, game maps with an innovation level of 7 had a user satisfaction level of 8. In comparison, in Call of Duty, game maps with lower innovation levels like that of the "Mexican Village" and "Coastal California Boardwalk" had the same moderately high level of user satisfaction (user satisfaction $=7$ ) as a game map with higher innovation ("Dark Campsite" at 7). Thus, the initial assumption that innovation would always create a more enjoyable gaming experience was not supported.

These results also indicate that there is no direct connection between innovation and user satisfaction. We must then ask what other factors contribute to user satisfaction? Is it the characters in the game, the specific missions, how the game is played? At the same time, can innovation impede enjoyment? Is it possible these players crave structure in their games and that the power to create is too open-ended? Only with further exploration into the online communities of these games can these questions be truly explored. It is however clear that innovation is not the only indicator or influencer of user satisfaction and digital entertainment firms should be aware of this fact.

That being said, Minecraft, the more innovative game, did have a higher level of user satisfaction overall compared to Call of Duty. We might then be able to conclude that while specific innovative portions of a game may not directly result in a better gaming experience, video game players are generally more satisfied with a gaming experience if there is some sort of innovative quality in that game. However, further research using a broader data pool, including more online communities and games that fall along the innovation spectrum, would be required in order to confirm such a thesis.

The data also suggests that Minecraft players experienced a greater fluctuation in the level of their user satisfaction compared to those playing Call of Duty, the game with less overall innovation. That is, in Minecraft the levels of user satisfaction varied within the range of 5 to 9 , while in Call of Duty user satisfaction was ranked at only 5 or 7 . This is interesting considering the lack of connection between innovation and user satisfaction. It is therefore unclear whether this fluctuation in user satisfaction is actually caused by the raised levels of innovation or if other elements of the game contribute to these inconsistent results.

Finally, and unsurprisingly, "radical innovation" - being an innovation level of 8 or higher was only found in the more innovative game (Minecraft). Considering innovation and user 
creativity seems to be the root of the Minecraft experience, any other result would be unexpected. The question then becomes: what is the impact of this radical innovation? What legal implications, particularly in the realm of intellectual property, does the power to create have on users and video game producers alike? These questions will now be explored.

\section{Copyright Implications}

It is assumed that the Minecraft's innovation discussed above stems mainly from its reliance on creativity and user-generated content (UGC). As noted by Lastowka, being a game that is primarily about making new things, Minecraft lets players "discover their own creativity," valuing this creativity to the same extent as the creativity of the game's creator. ${ }^{53}$ A perfect example of this process occurred while the game was in beta testing when the lead developer discovered that a 15 year old player named Hippoplatimus created a new modification called "pistons" that was posted and downloadable online. ${ }^{54}$ In fact, pistons were later incorporated into the game as an official modification and Hippoplatimus now receives credit in the game's end text. ${ }^{55}$ Official modifications are not the only medium for player creativity. Minecraft is fairly simple, and is considered an open-world or "sandbox" game. The player has no specific goals, but instead explores and creates within the game as desired.

This exploration and creativity is limitless within the game. Minecraft generates new terrain as the player explores its worlds, while these players collect and rearrange the game's elements into new structures and items. As noted by Schlinsog, "Within the game, dedicated users have created detailed reproductions of objects and spaces, such as the Enterprise from Star Trek and Kings Landing from Game of Thrones." In addition to these worlds, players have also created modifications like that by Hippoplatimus, which change how the game can be played. ${ }^{56}$ As such, UGCs are key to the Minecraft experience.

The question then becomes, what role does the law of copyright play within this new realm of gaming? Specifically, are the UGCs of Minecraft's players safe from copyright infringement

\footnotetext{
${ }^{53}$ Greg Lastowka, Minecraft, Intellectual Property, and the Future of Copyright (17 January 2012) Gamasutra: The Art \& Business of Making Games, http://www.gamasutra.com/view/feature/134958/minecraft_intellectual_property_.php.

${ }^{54}$ Melinda J. Schlinsog, Endermen, Creepers, and Copyright: The Bogeymen of User-Generated Content in Minecraft, 16 TUL. J. TECH. \& INTELL. PROP. 185 (2013)

${ }^{55} \mathrm{Id}$. at $185-6$.

${ }^{56} \mathrm{Id}$. at 186
} 
claims? The answer lies in whether or not the UGC, "falls in the core of copyrightable subject matter." 57

Although the idea of people creating their own content is not new to the law, UGCs in recent years have become a major social phenomenon with the rise of creation-sharing websites like YouTube and Facebook. To create a piece of UGC, a creator must make something that is not just a copy of pre-existing content. There must be an element of innovation and creativity in this new "thing." UGCs are then usually disseminated online, typically with large numbers of individuals viewing it after it is made. ${ }^{58}$ As such, Hetcher observes, “...the basic requirements for copyrightability - originality and fixation - appear to be easily satisfied, at least by substantial portions of UGC." 59 UGCs can be created by anyone at home, including the 15-yearold gamer as discovered during the development of Minecraft.

It is well established that video games are protected under the law as a recognized form of Intellectual Property. ${ }^{60}$ Copyright, patent, and trademark laws provide protections for game makers to "reap the benefits of their creativity" and sue individuals who seek to pirate or copy their work. These laws however, "generally discourage game developers from offering powerful creative tools to players."

Lastowka notes that this connection between video game creativity and copyright was perfectly exemplified in litigation between Marvel and NCSoft beginning in 2004 over the game "City of Heroes." In City of Heroes the game contained a "Creation Engine," which let its players create superhero costumes. Marvel sued over this tool, claiming that the game's players were creating costumes that looked like Marvel characters, like Wolverine and Iron Man, therefore infringing Marvel's copyrights. Marvel held the position that: “...because NCSoft made the tools that enabled the infringing costumes and hosted them on its servers, it should be liable for the player-created copyright infringements." 62

\footnotetext{
${ }^{57}$ Steven Hetcher, User-Generated Content and the Future of Copyright: Part One - Investiture of Ownership, 10:4 VANDERBILT J OF ENTERTAINMENT AND TECH. LAW 863 (2008)

${ }^{58} I d$.

${ }^{59} \mathrm{Id}$.

${ }^{60}$ Schlinsog, supra note 54 at 194-5 (concisely explains why video games are protected under copyright laws: video games qualify for copyright protection under computer programing as "literary works" and the audiovisual aspects as "audiovisual works." This means that both the underlying computer program and the audiovisual displays of a video game are protectable under the Copyright Act and thus the game as a whole is protected.)

${ }^{61}$ Lastowka, supra note 53.

${ }^{62}$ Id.
} 
Marvel's position would lead to the conclusion that hosts of online games would be liable for all player-created copyright infringements; if this were the case then no developer would ever host a sandbox game like Minecraft online. ${ }^{63}$ In 1998 Congress passed the Digital Millennium Copyright Act (DMCA) to provide online hosts with some protections from these risks. As discussed by Lastowka, the DMCA:

...Provides a safe harbor for service providers who unknowingly store infringing material that is created by users of the service: i.e. infringing superhero avatars created by players. However, to comply with the DMCA, the game company must follow certain formal requirements, including designating a DMCA agent and instituting a procedure for the swift removal of infringing content upon notification. ${ }^{64}$

NCSoft had complied with these DMCA rules by deleting many of the player-created costumes. Marvel however argued that this was not good enough and NCSoft was still liable due to it being "technologically complicit in the ongoing player infringements." The Federal Court never formally rejected this argument by Marvel, however the litigation ended when the parties settled outside of court. Lastowka notes that as a result of this case the issue of whether creative tools like the City of Heroes "Creation Engine" clearly infringe a party's copyrights is not conclusive. ${ }^{65}$

Although the NCSoft/Marvel case seems to be a warning against giving players creative tools within games, Minecraft does not face the same risks as NCSoft did. That is due to the fact that, unlike NCSoft, Minecraft does not host its players' content on proprietary servers and is therefore does not fall under the system of the DMCA and responsibility for its players' infringing creations. ${ }^{66}$ This is unique to many sandbox games, including famous ones like "Second Life." With Minecraft, a copy of the game's code is downloaded to the computer of the player where the game is run and solely hosted. ${ }^{67}$ As such, any of the copyright infringement burdens created by Minecraft players are pushed off the game on to those who do host the allegedly infringing content. ${ }^{68}$

\footnotetext{
${ }^{63}$ Ibid.

${ }^{64}$ Lastowka, supra note 53

${ }^{65}$ Lastowka further notes that DMCA is once again under attack in the pending Second Circuit Court of Appeals lawsuit between Viacom against YouTube.

${ }^{66}$ Ibid.

${ }^{67}$ Schlinsog, supra note 54 at 189.

${ }^{68}$ Lastowka, supra note 53.
} 
Schlinsog also looks at the contractual provisions Minecraft engages with its players in regards to UGCs. Throughout the terms and conditions that players must agree to before downloading the game, there are two important features. One: creativity and thus the development of UGCs are encouraged, and two: it is explicitly clear that the content remains private to said user-creator. As she notes, "[t]his promise of user-ownership for any usercreat[ion]...demonstrates not only [the game's] permission for UGC, but also its incentivization of it through an ownership rights guarantee."69

The next issue then is: can these UGCs themselves be afforded their own copyright protections? The aspects of the UGCs created within Minecraft are composed of elements that are legally protected: the game's code and visual displays. However, Schlinsog asks, "[Since] the user has created the [new] code within Minecraft's framework, using the platform of the game, does the UGC disqualify itself from copyright protection by copying the game's expression or being a derivative work?" Furthermore, although the building blocks of a player's UGC are technically copyrightable, if the work itself infringes on another's rights then the law will not protect it. $^{70}$

Finally, a player's UGC is likely not to be protected by the exemptions or defenses under the Copyright Act (the "Act") if found to be infringing. Under section 117 of the Act, adaptations of computer programs are exempted from copyright infringement. However, in MAI Systems Corp. $v$ Peak Computer Inc. the court found that "the benefit of adaption status did not vest in users who are licensing the content" and when the developer owned the copies of the software and only licensed its use the section 117 exemptions was not applicable. Since the terms and conditions of Minecraft specifically state: "Although we give you permission to play our Game, we are still the owners of it," the MAI finding would apply. ${ }^{71}$

The defense of fair use is found in section 107 of the Act, and allows copyrighted material to be used without consent of the owner in certain circumstances. When determining if the doctrine of fair use applies, the Act provides four factors to be considered: (1) the purpose and character of the use in question, (2) the nature of the original work, (3) the amount and substantiality of the used portion in relation to the whole original work, and (4) the effect of the new use on the

\footnotetext{
${ }^{69}$ Schlinsog, supra note 54 at 192.

${ }^{70} \mathrm{Id}$.

${ }^{71} \mathrm{Id}$.
} 
original work's potential market or value. Precedents however have not clearly indicated whether a player's UGC is "fair use" of a game. ${ }^{72}$ That being said, the case law seems to focus on protecting the copyright owner's market over the user's right: in Micro Star v Formgen Inc., fair use was not found, one of the reasons being that the copyright owner was "the only party allowed to commercial and market derivative versions, even if that right was not utilized."

Schlinsog concludes that "under such a protectionist precedent, UGC in Minecraft is likely to function as a derivative that only the owner can market, and, thus, to fail the fair use test." Schlinsog, however, also argues that the precedents are flawed. A focus on the importance of commercial use does not consider the important and positive roles game modifications like UGCs have in the game's market. Secondly, she states that the past decisions did not consider whether gaming UGCs are transformative works, which she believes there is a viable argument that they are. The more transformative a work, the more likely factors that would weigh against a finding of fair use would be weighed less heavily. ${ }^{73}$

So, in the end, it is clear that Minecraft wants its players to be creative, and it seems that by not hosting any of its players' creations the game is not liable for any UGCs that may infringe another party's copyrights. The UGCs themselves however, despite being comprised of copyrightable elements, are likely to be considered infringing works and may not be protected or exempted under the Act. As Schlinsog effectively concludes: "Despite the contractual rights that games like Minecraft accord, UGC will continue to be a second-class form of expression until protected by copyright law." ${ }^{\prime 4}$ With Minecraft's push to inspire innovation in its players, is the game in a way pushing its players to break copyright laws? Or is the push really against the boundaries of copyright and the law has just not yet reached the next level?

\section{Conclusion}

This paper sought to explore the implications of innovation on marketplace and its transformative influence on the traditional understandings of consumer-producer relationships. To do this, the authors focused their research towards the role innovation is playing within the digital entertainment marketplace, specifically looking at the video game industry and taking

\footnotetext{
${ }^{72}$ Ibid.

${ }^{73}$ For further discussion on this relevant precedent case law see Schlinsog, supra note 54.

${ }^{74}$ Schlinsog, supra note 54 at 206.
} 
data from the industry's digital consumer networks. Through investigating the relevant theoretical frameworks for this study, this paper noted that the exercise of radical innovation by one firm could challenge another's monopoly over a marketplace. Minecraft has illustrated this through its entry into the video game marketplace and its radical innovation.

This paper then moved from discussing its theoretical basis to the data collected from the online communities of Minecraft and Call of Duty. The authors assumed that there would be a positive correlation between innovation and user satisfaction, and as such user satisfaction would be higher in Minecraft. However, no significant correlation was found between innovation and user satisfaction after the data was measured. Thus, although Minecraft has successfully challenged the traditional monopolies within the digital entertainment industry as a radically innovative firm, additional research must be conducted to truly understand whether innovation and consumer satisfaction really go hand-in-hand and impact market success.

The research question explored in this paper also led to further concerns regarding the implications of user-generated digital content to the relationship between the video game industry and intellectual property laws. Specifically, with Minecraft's focus on and support for user creativity, questions arise regarding whether the materials created by Minecraft players are safe from copyright infringement claims or even copyrightable subject matter in themselves. The available precedents on the matter have not yet decisively concluded where these forms of expression lie within the copyright regime. It is likely that if a UGC is comprised of another's copyrightable elements it will be considered infringing and not protected under law, although Minecraft would not be held liable due to the system they have established regarding the hosting of these materials. Yet the push for user-generated digital creative expression exposes a flaw in copyright laws, as without protection the UGC will remain "a second-class form of expression."75

We are, therefore, left with two conclusions on the matter. First, despite the evolving collaborative relationship between producers and consumers within the marketplace, within the video game industry specifically it cannot unequivocally be said that a user with more creative control has a better experience as a consumer of a product. Second, the push for innovation and

${ }^{75}$ Schlinsog, supra note 54 at 206. 
user-generated content puts players of sandbox games like Minecraft in a precarious spot within the copyright regime, likely unprotected from infringement claims that may arise against them.

If this is where we lie, should video game producers really push to be more innovative like the run-away hit Minecraft proved to be, or should they stay the course with the traditional approach to video game design that Call of Duty has successfully embarked on? Further research should thus be conducted on the additional elements that feed user satisfaction and the other benefits innovation may have for consumers and producers both socially and economically.

It is true that the marketplace is constantly evolving, especially with the availability of technological tools and advancements that bring consumers and producers closer together. However, it is unclear whether the pursuit of consumer innovation is truly a fruitful one, or whether it is just a passing trend. We will just have to wait and see how many people continue to play in the "sandbox", and how many leave for whatever the newest shiny toy on the digital entertainment playground will be. 